Iraqi J. Vet. Med. 34 ( 2 ): 39 - 44; ( 2010 ).

\title{
Prevalence of Listeria in ice creams in Baghdad province
}

Ali Hassan Ahmed AL-Shamary

Vet. Public Health /Food hygiene /Milk hygiene Coll. Vet. Med. /Baghdad University

Accepted - November $\mathbf{- 2 0 1 0}$

\section{Summary}

The aim of this study was concerned on the prevalence of Listeria spp.in the ice cream samples collected from the different pastry shops and downtown stores of Baghdad province during December 2009 till April 2010. A total of 50 ice cream samples (25 locally produced samples from raw and imported powdered milk and 25 imported samples from different origins) were analyzed and processed according to the standard protocols of Food and Drug Administration (FDA) and International Organization for Standardization (ISO) with some modifications. Growth of Listeria spp. was determined in $7(14 \%)$ of total samples as $4(16 \%)$ isolates from locally produced ice creams, from which one isolate was confirmed as Listeria monocytogenes, and $3(12 \%)$ isolates from imported ice creams. The findings of this study suggest that Listeriacontaminates some dairy products and Listeria infections are not a potential risk in Baghdad province, but it is strongly recommended that these products are monitored carefully.

Key Words: Listeria monocytogenes, Listeria spp., ice cream, food microbiology. Mobile No.07702516727

$$
\begin{aligned}
& \text { التحري عن اللستيريا في المثلجات اللبنية في مدينة بغداد }
\end{aligned}
$$

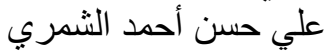

$$
\begin{aligned}
& \text { صحة عامة بيطرية /صحة غذاء/صحة حليب كلية الطب البيطري /جامعة بغداد }
\end{aligned}
$$

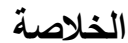

$$
\begin{aligned}
& \text { أستهدفت الدراسة التحري عن نواجد جرثومة اللسنتيريافيالمنجات اللبنية المباعة في الأسواق } \\
& \text { المحلية في مدينة بغداد للمدة من كانون الأول } 2009 \text { ولغاية نيسان } \\
& 25 \text { أنموذج من المنلجات اللبنية المصنعة محليا من مصادر حليب مختلفة المنشأ ( حليب خام و ولاول }
\end{aligned}
$$

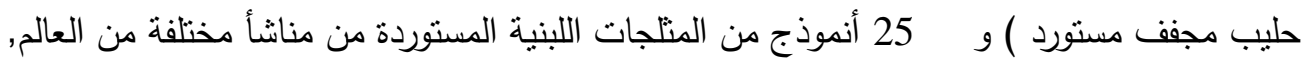

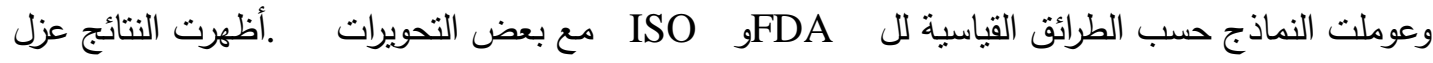

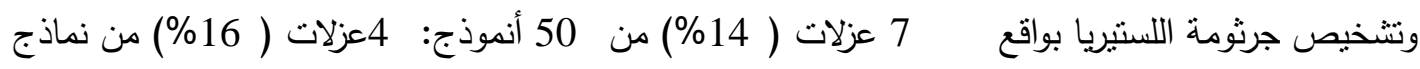

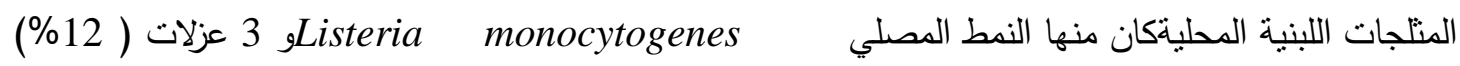

$$
\begin{aligned}
& \text { من نماذج المتلجات اللبنية المستوردة.نستتتج من هذه الدراسة تلوث بعض منتجات الحليب بجراثيم } \\
& \text { اللستيريا وينصح بمراقبة المنتجات اللبنية المصنعة محليا و المستوردة لضمان الصحة العامة. }
\end{aligned}
$$

\section{Introduction}

Listeria especially Listeria monocytogenes are gram-positive, rod-shaped bacteria found in soil, stream water, sewage, plants and food especially in raw, unpasteurized milk and its products as well as, in low grade quality and post-thermal treated products of food especially milk $(1,2,3 \& 4)$. They are responsible for listeriosis, a rare but potentially lethal food borne infection ranging from flu-like syndrome or gastroenteritis to deadline infection of nervous system causing meningitis and abortion in pregnant women (3). Listeria species are incredibly and hardy able to grow in refrigerator at $4 c^{\circ}$ to $37 c^{\circ}$ the body's internal temperature (3). The presence 
of any Listeriaspp. in food may be an indicator of poor hygiene (2). Ice cream, a dairy product consumed with pleasure by the general populace, especially children due to its contents of sweeteners, aromatic compounds and various fruits, is known to be the richest in terms of content among the dairy products (5). Milk and dairy products under low temperature especially ice cream, constitute a potentially risk for listeriosis (5\&6). Unfortunately, in Iraq country most of the consumed milk and dairy products are not prepared under hygienic conditions (1). Ignorant producers utilize milk that is most often not boiled enough in the production of their products, as well as, random importation of low quality milk and dairy products from different origins; this obviously affects the health of the consumers (1).Quality of ice cream depends on both extrinsic factors that include manufacture procedure, and intrinsic factors that include proportion of ingredients used (7). Ice cream, a milk based product is good media for microbial growth due to its high nutritive value, almost neutral $\mathrm{pH}$ value and long storage duration (6\&7). Primary sources of microbial contamination to the ice cream include water and raw milk whereas secondary sources include flavoring agents, utensils and handling (7).Although pasteurization, freezing and hardening steps in production can estimate most of the microbial hazards, but still numerous health hazards are persistent due to various conditions (8). Many psychrophiles and psychrotolerant microorganisms like Listeria monocytogenes, Staphylococcus aureus, Bacillus species, Salmonella species, Shigella species, Streptococus spp., Pseudomonas spp., Campylobacter spp., Brucella spp. and coliform bacteria are generally present in ice cream (4).There are few studies on the presence of Listeriaspp. in ice cream, so that, this study was designed for determining the level of contamination of imported and locally produced ice cream samples from across our region.

\section{Materials and Methods}

Collection of Ice Cream Samples:This study was conducted on ice cream sold in different locally markets in Baghdad province.The origins of the milk samples used for producing the ice creams were different from locally raw, unpasteurized milk to imported milk powder. A 50 ice cream samples (25 locally produced and 25 imported) were collected into sterile containers and transported under coolingto the laboratory of food hygiene in Baghdad Veterinary College during December 2009 till April 2010.

Isolation of the Listeria species:The ice cream samples were thawed to below room temperature and a $25 \mathrm{ml}$ from each was mixed with a $225 \mathrm{ml}$ Trypton Soya Yeast Extract Broth (HiMedia, India) according to standard protocols, in which a portion of analytic sample was added to 9 portions of Listeria enrichment broth $(9,10 \& 11)$. For a homogenous distribution, the sample in the medium was shaked for 2-3 minutes inside stomacher. The inoculated media were then incubated at $30 \mathrm{C}^{\circ}$ for $24-48$ hours. After 24 and 48-hour enrichment processing, the culture was made on the Listeria Selective Agar (PALCAM, Oxoid). The planted plates were incubated for 48 hours at $(35-37) \mathrm{C}^{\circ}$ under aerobic conditions. At the end of the incubation, they were evaluated as typical colonies with black haloes of 1-3 mm in diameter. The typical Listeria colonies observed on the culture medium were selected and cultured separately in Trypton Soya Yeast Extract Agar (HiMedia, India). After that, the colonies were 
checked morphologically and their purity controlled by gram staining. Later, the separated colonies were then subjected to carbohydrate fermentation tests (mannitol, D-xylose, rhamnose), catalase activity, oxidase activity, modified motility test with triphenyltetrazolium chloride salts (Umbrella formation), esculin hydrolysis. The colonies isolated as Listeria were then subjected to $\beta$-hemolysis in a 7\% sheep blood agar for species identification. Confirmation of Listeria isolates was done by Latex Agglutination test (Oxoid, UK), and differentiation of Listeria monocytogenes from other Listeriaspp. was done by Oxoid Biochemical Identification System (O.B.I.S.mono test kit, Oxoid) (12).

\section{Results}

Results revealed that out of the 50 ice cream samples, 7 samples (14\%) were contaminated with different Listeria species as $4(16 \%)$ isolates from locally produced ice creams, from which one isolate was confirmed as Listeria monocytogenes, and 3 (12\%) isolates from imported ice creams as shown in table (1).

Table (1).Isolation of Listeria species from Baghdad province.

\begin{tabular}{|c|c|c|c|c|}
\hline Sample Type & Number & Listeria spp. & Listeria monocytogenes & Total \\
\hline Ice creams & 50 & $6(12 \%)$ & $1(2 \%)$ & $7(14 \%)$ \\
\hline Locally produced & 25 & $3(12 \%)$ & $\mathbf{1}(4 \%)$ & $\mathbf{4}(16 \%)$ \\
\hline Imported & 25 & $3(12 \%)$ & None & $\mathbf{3}(12 \%)$ \\
\hline
\end{tabular}

Listeria monocytogenes appeared on chromogenic PALCAM (Polymyxin Acriflavin Lethium Chloride Ceftazidime Aesculin Mannitol) agar as grayish-green, smooth, convex, circular or creanated colonies with entire margins, black haloes of 1-3 $\mathrm{mm}$ in diameter and sunken center; after 5 days, they became brown-black, enlarged in size with black haloes of 3-5 $\mathrm{mm}$ in diameter lock like bull or fish eyes and medium became cherryred; while other Listeria spp. appeared as grayish-whitish and some types as grayish-yellowish with black centers (13). The results of biochemical tests, Listeria latex agglutination test and O.B.I.S.mono test to differentiate Listeria monocytogenes from other Listeria spp. are summarized in table (2). 
Iraqi J. Vet. Med. 34 ( 2 ): 39 - 44; ( 2010 ).

Table (2). Listeria biochemical's and confirmation tests.

\begin{tabular}{|c|c|c|}
\hline Test & Listeria monocytogenes & Listeria spp. \\
\hline Gram-positive rod & + & + \\
\hline Umbrella formation & + & - \\
\hline p-Hemolysis & + & - \\
\hline Catalase activity & + & - \\
\hline Oxidase activity & + & + \\
\hline esculin hydrolysis & + & V \\
\hline Rhamnose fermentation & + & V \\
\hline D-Xylose fermentation & + & + \\
\hline Mannitol fermentation & - & V \\
\hline Oisteria latex agglutination & + & + \\
\hline
\end{tabular}

$+=$ positive test, - = negative test, $\mathbf{v}=$ variable results and +++ = strongly fast positive result

\section{Discussion}

Listeria species are found in almost every medium in the environment including soil, excrement, canalization waters, plants, animals, animal feeds and foods; they contaminate milk by various means from these sources (14). These microorganisms, because its psychrotrophic genetic ability can grow and contaminate of ice cream due to its a complex food containing sugar, emulsifiers and fats(15).In our country, studies on the prevalence of Listeria in ice cream are limited in number, I found Listeria spp. especially Listeria monocytogenes in raw, unpasteurized milk and soft cheese from different animal species (1). This study revealed isolation of Listeria spp. from locally produced and imported ice cream samples either due to poor hygienic measurements and poor surveillance on product or contamination during production, processing, transportation and storage. From several studies on the prevalence of Listeriaspp. in milk and dairy products, various Listeriaspp. including Listeria monocytogenes have beenisolated (16). Other countries such as USAshowed that in a factory dealing with frozen milk and dairy products in California, 922 samples were taken from the different divisions of the factory, Listeria spp.were isolated in 111 $(12.04 \%)$ samples, and of the 39 examined factories,Listeria monocytogenes was encountered, in only 5, whilst 13 of them contained Listeria innocua, in 9 of them 
Iraqi J. Vet. Med. 34 ( 2 ): 39 - 44; ( 2010 ).

both species were encountered, and in 12 factories no isolates were encountered (17). Farber (18), in a study in which 394 ice cream samples were examined, found the incidence of Listeria monocytogenes to be $0.25 \%$ (12). Pak . (19), in a study on dairy products in 2002, found the incidence of Listeria monocytogenes to be $4.9 \%$. In the same study, whilst the incidence of Listeria monocytogenes was 7.6\%, Laciar . (20), in their study in Spain in 1999, investigating the presence of Listeria spp. in different food items, failed to isolate Listeria spp. in pasteurized milk, cheese and chocolate milk products but Listeria welshimeri was isolated from ice cream samples. Casedei (21), in 1998 and Manifreni . (22), in 1993 in their studies on ice cream samples couldnot isolate the known pathogen Listeria monocytogenes. In 1999, Laciar . (20), in their study on ice cream samples reported that Listeria monocytogenes could not be isolated.

In conclusion, sinceListeria species were found to a large extent in our ice cream samples andListeria monocytogenes was encountered, it should be mandatory to perform routine controls to screen ice cream samples for detection of Listeria spp. Our findings suggest that Listerial infections are not a potential risk in Baghdad province; it is strongly recommended however that these products are monitored carefully. The results obtained showed differences between the hygiene and bacteriological quality of commercial and homemade ice creams. The implementation of Hazard Analysis and Critical Control Points (HACCP) Programs in ice cream industries is essential for addressing food safety for population of Baghdad province, as well as intervention and education of people involved in the production of house made ice creams and monitoring the imported ice creams.

\section{References}

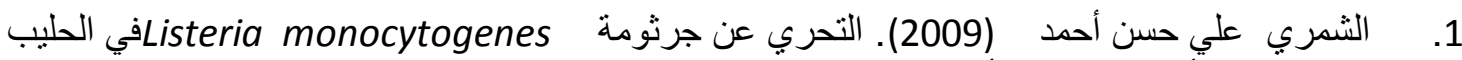
وبعض منتجات الألبان في بغداد , أطروحةدكتور اهركلية الطب البيطري,جامعة بغداد.

2. RyserET (1999). Foodborne listeriosis, Pp: 299-358. In: Ryser, E.T. and Marth, E.H. (ed.),Listeria, Listeriosis and Food Safety. 2nd ed. Marcel Dekker Inc. NewYork, USA.

3. Dong you Liu (2008). Handbook of Listeriamonocytogenes. $1^{\text {st }}$ ed., CRC Press, USA.

4. Jay JM Loessner MJ and Golden DA (2005). Modern Food Microbiology, $7^{\mathrm{h}}$ ed., AspenPub. Gathersburg MD, USA.

5. Akman D Nizami D and Diúrak M(2004) Prevalence of Listeria Species in icecreams soldin the citiesof Kahramanmaraß and Adana Turk J Med Sc. 34:257-262.

6. Gougouli M Angelidis AS and Koutsoumanis KA (2007).Study on the kineticbehavior ofListeria monocytogenes in ice cream stored under static anddynamic chilling and freezing conditions. J Dairy Sci. 91:523-530.

7. Windrantz P Arias ML(2000). Evaluation of the bacteriological quality of icecream sold at San Jose, Costa Rica. Arch. Latinoamer. Nutric. Caracas50(3):301-303.

8. Joshi DR Shah PK Manandhar S Sharma S and Banmali P (2004). Microbialquality of ice creamsoldinkathmandu. J Nepal Health Res Council. 2(2): 37-40.

9. Hitchins AD (2003). Detection and enumeration of Listeriamonocytogenes in foods. Chapter 101. In: Jackson GJ (coordinator), Bacteriological Analytical manual. $10^{\text {th }}$ ed., Revision A., AOAC Int. Gaithersburg M.D.USA.

10. FDA Food and Drug Administration. Bacteriological analytical manual. 8. Ed. Gaithersburg, 1995. 562p. 
Iraqi J. Vet. Med. 34 ( 2 ): 39 - 44; ( 2010 ).

11. ISO International Standards Organization. (1996). 11290-1, Microbiology of food and animal feeding stuffs-horizontal method for the detection and enumeration of Listeriamonocytogenes- Part-1: detection method, London: British StandardsInstitute (BSI).

12. Pagotto F Daley E Farber J and Warburton D (2001). Isolation of Listeriamonocytogenes from all food and environmental samples. MFHPB-30, Health products and food branch, HPB Method, Ottawa, Canada.

13. Van-Netten P Perales I Van de Moosdijk A; Curtis GD and Mossel DA (1989).Liquid and solid selective differential media for the detection and enumerationof Listeria monocytogenes and other Listeria spp. Int. J. Food. Microbiol, 8(4):299-316.

14. McLauchlin J and Rees CED (2008). Genus Listeria. In: Bergey's Manual of Systematic Bacteriology, $2^{\text {nd }}$ ed., The low $\mathrm{G}+\mathrm{C}$ gram positive bacteria, Vol. 3, eds. Devos P; Garrity G; Jones D; Krieg NR; Ludwig W; Rainey FA; SchleiferKH and Whiteman WB; Williams and Williams, Baltimore, M.D. USA.

15. AbrahãoI WM brahãoII PA MonteiroII CL and PontaroloI R (2008). Occurrence of Listeria monocytogenes in cheese and ice cream produced in the State ofParaná, Brazil. Revista Brasileira de Ciências Farmacêuticas. $44(2)$ :

16. Jayarao MB Donaldson SI Straley BA Sawant AA Hedge NV and Brown JL(2006). A Survey of foodborne pathogens in bulk tank milk and rawmilkconsumptions among farm families in Pennsylvania.JDairySci.89:2451.

17. Walker RL Jensen LH Kinde H (1991). Enviromental survey for Listeria species in a frozen milk products plant in California. J Food Protec 54(3): 17882.

18. Farber JM Sanders GW Johnston MA (1989). A survey of various foods for the presence of Listeria species. J Food Prot 52(7): 456-8.

19. Pak SI Spahr U Jemmi T (2002). Risk factors for Listeria monocytogenescontamination of dairy products in Switzerland, 1990-1999. Prev Vet Med 14; 53(1-2): 55-65.

20. Laciar AL Vaca L(1999). Centorbi on. Listeria spp. In food of animal origin. Rev Argent Microbiol 31; 1: 25-30.

21. Casadei MA Esteves MR Harrison ST Gaze JE (1998). Heat resistance of Listeriamonocytogenes in dairy products as affected by the growth medium. $\mathbf{J}$ Appl Microbiol 84: 234-9.

22. Maifreni M Civilini M Domenis C(1993).Microbiological quality of artisan ice cream. Zentrabi Hyg Umweltmed 194: 553-70. 